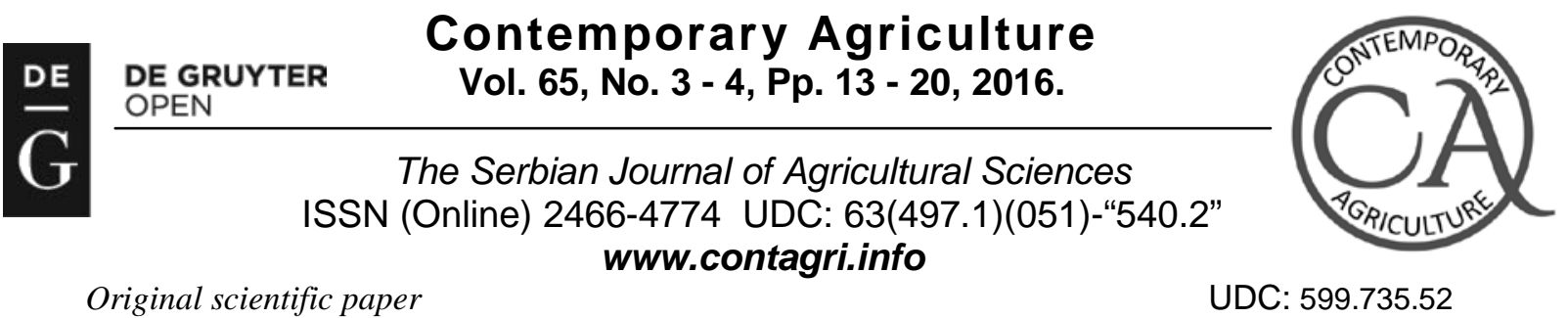

DOI: 10.1515/contagri-2016-0012

\title{
NEMATOPHAGOUS ACTIVITY OF DUDDINGTONIA FLAGRANS MUCL 9827 AGAINST SHEEP GASTROINTESTINAL NEMATODES*
}

\author{
Stanislav SIMIN*, Simonida ĐURIĆ, Ljiljana KURUCA, Timea HAJNAL-JAFARI, \\ Dragana STAMENOV, Vesna LALOŠEVIĆ ${ }^{1}$,
}

\begin{abstract}
Summary: Gastro-intestinal nematodes (GIN) of sheep are one of major constraints in grazing production systems worldwide. Control is commonly achieved using anthelmintics, but global occurrence of anthelmintic resistance to different drugs and the emergence of multi-resistant GIN species seriously limit the efficiency of their use. Therefore, integrated parasite management is widely recommended, with nematophagous fungi as one of control tools. Duddingtonia flagrans is one of the most used species, with various effect of different isolates. In previously performed coproculture assay, we showed low efficacy of D. flagrans MUCL 9827 against infective larvae (L3) of sheep GIN. The aim of current experiment was to reevaluate its nematophagous potential, using the medium where direct interaction between the fungus and L3 could be observed. Nematophagous activity was tested on $2 \%$ water agar with addition of chloramphenicol on three series of plates seeded with 500 and 1000 chlamidospores and agar blocks with 7 days old mycelium. At Days 0 and 5, 500 L3 of sheep GIN were added to test the trapping activity. The cultures, including control plates with only L3, were incubated at $25^{\circ} \mathrm{C}$ for 10 days, followed by evaluation of their number and reduction percentage. Nematophagous activity of D. flagrans MUCL 9827 against L3 was clearly demonstrated. However, the overall efficacy was poor since trapping was observed only in one out of nine plates containing fungal material. Potential reasons for such poor performance of the isolate of fungal species, otherwise known as successful in trapping animal parasitic nematodes, are discussed.
\end{abstract}

Key words: Duddingtonia flagrans, MUCL 9827, sheep, gastro-intestinal nematodes, nematophagous activity.

\section{INTRODUCTION}

Grazing is economically justified practice in sheep production since these animals the most rationally transform the grass to proteins necessary for human consumption (Vujić et al., 1980). However, in this management system, it is practically impossible to avoid the invasion of different types of parasites that contaminate pastures. Invasion with ubiquitous gastro-intestinal nematodes (GIN) is the most important limiting factor in the intensive sheep breeding around the world, due to economic losses and the specificities of different ways for its control (Vujić et al., 1980; West et al., 2009). Different measures against GIN include controlled grazing, breeding and nutrition strategies, anthelmintic drugs and biological control. The use of anthelmintic drugs was the main control tool in the past since it is the easiest, the most efficient and the cheapest, and there is a tendency that this will continue in the future (Cvetković, 1976; Sargison, 2012). However, the development and the worldwide extent of anthelmintic resistance (AR) to different drug classes, with frequent occurrence of multi-drug resistant isolates, threaten the sustainability of their use (Kaplan, 2004; Papadopoulos et al., 2012; Rose et al., 2015). Similar to other countries, there is preliminary evidence of AR to ivermectin in Serbia as well (Simin et al., 2014), which is later confirmed (Simin et al., in preparation).

In sheep flocks where the reliance to drugs is the sole option for GIN control, the accumulation of resistant nematodes that could negatively affect the life, health, welfare and productivity of animals is the most important issue of contemporary production. That is why the integrated parasite control strategy was developed, with main goal

\footnotetext{
${ }^{1}$ Stanislav Simin, DVM, MSc, Teaching Assistant; Ljiljana Kuruca, DVM, MSc, Research Associate; Vesna Lalošević, PhD, Full Professor, University of Novi Sad, Faculty of Agriculture, Department of veterinary medicine, Trg Dositeja Obradovića 8, 21000 Novi Sad; Simonida Đurić, PhD, Associate Professor; Timea Hajnal-Jafari, PhD, Assistant Professor; Dragana Stamenov, PhD, Senior Research Associate; University of Novi Sad, Faculty of Agriculture, Department of field and vegetable crops, Trg Dositeja Obradovića 8, 21000 Novi Sad, Serbia.

*This research was supported by the Ministry of Education, Science and Technological Development of the Republic of Serbia (project grant No.TR 31027)

‘Corresponding author: e-mail: stanislav.simin@polj.edu.rs, Tel.: +38163/781-54-67
} 
to fight against GIN using combined measures approach (Waller, 1999). The use of nematophagous fungi to limit pasture infectivity is one of the most promising tools of integrated control, with Duddingtonia flagrans as one of the most efficient species because of its ability to survive the passage through animals digestive tract and trap larvae in faeces (Larsen, 1999). This leads to decrease of larval population on herbage resulting in lower availability for sheep, which prevents both clinical and subclinical infection.

Different isolates of $D$. flagrans examined in numerous experiments with number of nematode species of domestic and some wild animals showed various level of trapping activity. In previous trial we have evaluated the isolate of $D$. flagrans MUCL 9827 against infective larvae (L3) of sheep GIN in coproculture assay, but its efficacy, measured through larval reduction percentage, was low (Simin et al., 2012). The aim of this experiment is to examine in vitro nematophagous activity of the isolate against sheep L3 on different medium, where direct interaction between fungus and L3 could be observed.

\section{MATERIAL AND METHODS}

Fungus isolate. D. flagrans MUCL 9827 was obtained from Mycothèque de l'Université Catholique de Louvain (MUCL), Belgium. The isolate was first discovered in England by Duddington (1949), named as Trichothecium flagrans, and deposited to fungal collection of Centraalbureau voor Schimmelcultures (CBS) in Utrecht, Netherlands in 1950, where it got identification number CBS 565.50. In 1968 CBS deposited the isolate to MUCL in Belgium, where it was designated as MUCL 9827 (http://bccm.belspo.be/catalogues/mucl-strain-details?NUM=9827). The species was named as Duddingtonia flagrans by Cooke (1969) and renamed to Arthrobotrys flagrans by Scholler et al. (1999), but similarly to others (Skipp et al., 2002; Wang et al., 2015), we used the name $D$. flagrans to maintain continuity in publications regarding biological control.

Preparation of culture media and fungal suspension. D. flagrans MUCL 9827 was grown for four weeks in commercial potato dextrose agar (PDA; Biolife, Italy) at $25^{\circ} \mathrm{C}$ before the start of the trial, to collect chlamidospores. Nematophagous activity of the isolate against infective larvae (L3) of sheep GIN was tested on 2\% water agar with addition of chloramphenicol to inhibit bacterial growth (2\% CHF-WA), which was prepared according to Shams Ghahfarokhi et al. (2004). Chlamidospores of $D$. flagrans were collected in suspension and their number per milliliter was determined as described in previous experiment (Simin et al., 2012).

Preparation of infective larvae. Faeces were collected from 10 naturally infected ewes from a sheep farm in Srbobran, Vojvodina province, where Haemonchus contortus predominates. The samples were pooled, and incubated for 7 days at $27^{\circ} \mathrm{C}$ to collect L3 according to Roberts and O'Sullivan (1950). After collection, L3 were cleaned with sucrose (MAFF, 1986) and the number per milliliter of suspension was determined. L3 were not identified to genus/species level.

Trial design. Nematophagous activity of $D$. flagrans MUCL 9827 was evaluated according to Gonzales Garduno et al. (2005) and Campos et al. (2009), with some modifications. The growth of isolate and interaction with L3 were examined on $2 \%$ CHF-WA poured in four series of three small diameter $(5.5 \mathrm{~cm})$ Petri plates. In the first series, $D$. flagrans was cultivated for 7 days on PDA as described above, and then a piece of medium (6 mm diameter) with one week old mycelium was placed in the centre of each plate using agar block technique (Shams Ghahfarokhi et al., 2004). The plates from series 2 and 3 were seeded with 500 and 1000 chlamidospores, respectively, and cultivated for 7 days at $25^{\circ} \mathrm{C}$. At Days 0 and 5 of the trial, $500 \mathrm{~L} 3$ were added to all plates (including three series with $D$. flagrans and control with no fungal material). All plates were incubated at $25^{\circ} \mathrm{C}$ during 10 days in the dark, and trapping activity was monitored under stereomicroscope (A. Krüsse Optronic, Germany) at magnification of 40x. Trapped larvae were imaged using BIM-321T trinocular microsope (Budapesti Távcső Centrum, Budapest, Hungary).

Calculation of reduction and statistical analysis. After 10 days, the agar from all series was removed from Petri plates using metal spatula, wrapped in gauze and L3 were collected using Baermann technique (Zajac and Conboy, 2006). The number of remaining L3 in for each plate was determined. Percentage of reduction (PR) of larvae was calculated according to Terrill et al. (2004): PR= 100 - (mean larval yield in fungus group x 100/ mean larval yield in control group). The effect of $D$. flagrans MUCL 9827 against L3 was assessed using one-way ANOVA in Statistica XIII ( $\leq 0.05)$.

\section{RESULTS}

The viability of L3 on 2\% CHF-WA was good during the study period. Since some dead L3 were observed at Days 3-5, addition of 500 new L3 at Day 5 ensured that there was a sufficient number of L3 which actively migrated through the mycelium. 
The growth of the mycelium was different between series. In series 1, mycelium of D. flagrans MUCL 9827 slowly expanded from centered PDA disc during the study period. However, it did not reach the edge of $5.5 \mathrm{~cm}$ Petri plate even after 10 days of observation. In series 2 and 3, mycelium sparsely covered the whole surface of $2 \%$ CHFWA during first 7 days, and there was no significant change in its development during the trial.

Nematophagous activity of D. flagrans MUCL 9827 against L3 of sheep GIN was observed, with L3 being captured in the head, body and tail region (Image 1).
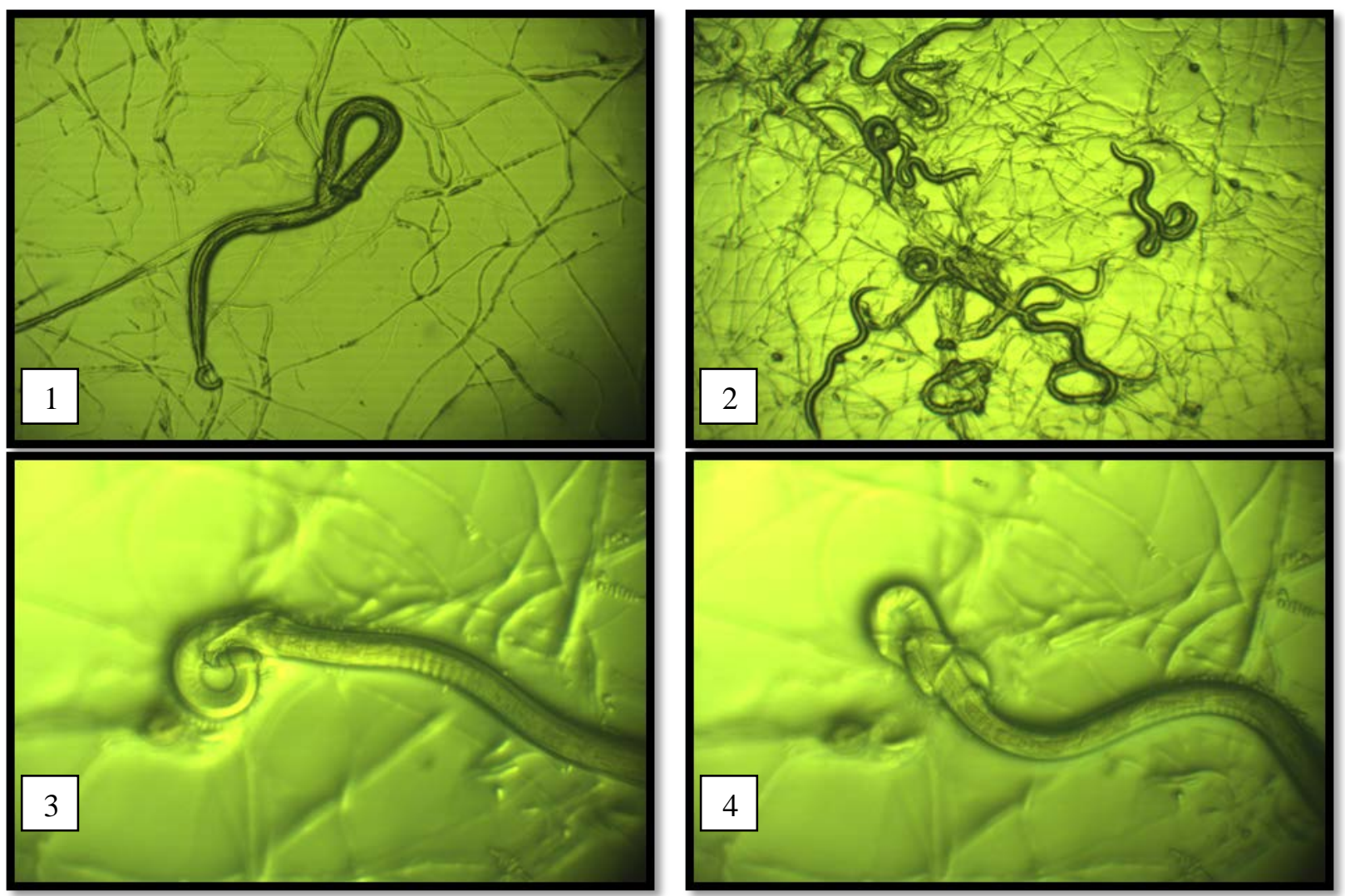

Image 1. Nematophagous activity of D. flagrans MUCL 9827: one (1; magnification 100x) and many trapped L3 (2; magnification 40x); L3 caught in the head (3) and oesophageal (4) region (magnifications 250x).
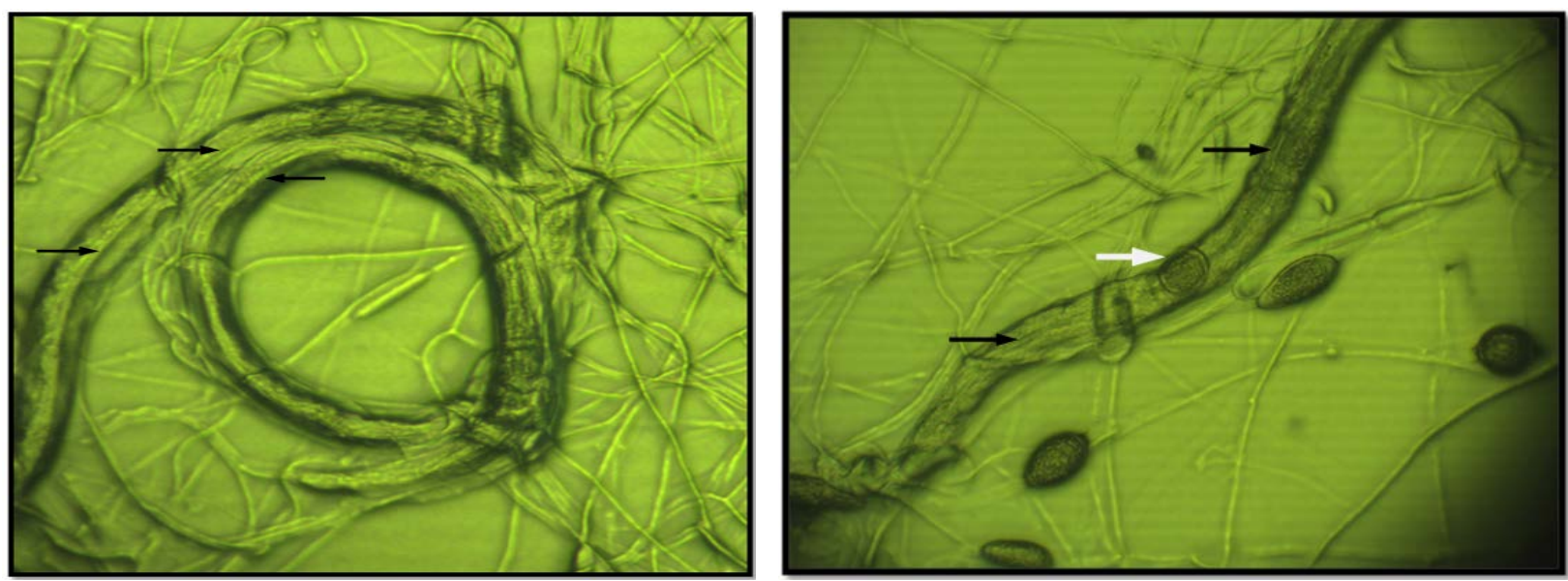

Image 2. Nematophagous activity of $D$. flagrans MUCL 9827: trophic hyphae (black arrows) and chlamidospore (white arrow) within the body of L3 (magnifications 250x). 
However, the activity was very low, since it was observed in only one (series 3) out of nine plates with fungal material. For that reason, calculation of neither PR nor statistical analysis was performed. Poor activity was observed due to almost complete absence of traps. In almost all cultures only a trap-like loops of mycelium were observed, but L3 undisturbedly wriggled through them. The adhesive network developed only in the plate seeded with 1000 chlamydospores and massive trapping occurred in 24 hours after addition of L3. In that plate, traps were not formed diffusely but were located in three separate areas on agar surface. The L3 were trapped only in those areas and no further trap development was recorded even after addition of new L3 at Day 5. Stagnation in trapping activity was observed after the first 24 hours, with only a few new L3 caught at a daily basis until Day 7 . There was still a number of active L3 moving freely across agar surface, which were not trapped until the end of observation period. At Day 10, some of previously caught L3 freed from mycelium and moved with detached traps adhered to their body.

In trapped L3, there was evidence that they were used as a food source for fungal colony, since trophic hyphae and chlamidospores were developed within their body (Image 2).

\section{DISCUSSION}

Current findings clearly proved nematophagous activity of $D$. flagrans MUCL 9827 against L3 of sheep GIN. Furthermore, the finding of trophic hyphae and chlamydospores within the body of L3 proved that they were used as a food source by fungal colony since chlamydospores in larval body form after digestion occurred (Wang et al., 2015). The existence of predatory behavior of $D$. flagrans MUCL 9827 is in accordance with findings of Duddington (1949) who also observed trapping effect during isolation process. On the contrary, Waller and Faedo (1993) and Den Belder and Jansen (1994) did not observe predation of this isolate against sheep and root knot nematodes, respectively.

Quantitative evaluation of isolate ability to reduce the number of L3 on 2\% CHF-WA was missed due to absence of nematophagous activity in almost all cultures. The lack of predation was firstly attributed to sparse mycelium growth of the isolate. Boguś et al. (2005) tested several isolates of $D$. flagrans on different solid and liquid media, and determined that $D$. flagrans CBS 565.50 (or MUCL 9827) grow more slowly than others on some substrates (e.g. Saburaud dextrose agar). Also, this isolate grows better on nutrient rich media compared to poor (Boguś et al., 2005), and the appearance of sparse colonies on $2 \%$ WA is considered as typical of $D$. flagrans (Chandrawathani et al., 2002; Shams Ghahfarokhi et al., 2004; Gonzales Garduno et al., 2005). Slower growth in vitro does not necessarily mean poorer nematophagous activity. For example, Danish isolates that grow faster on culture media did not have better trapping results compared to slower ones (Fernández et al., 1999). Also, hyphal density does not determine the trapping ability of nematophagous fungi, as shown in three isolates of Arthrobotrys oligospora (Den Belder and Jansen, 1994). Despite poor growth on the same medium, other researchers found very good activity of other isolates of D. flagrans against different animal parasitic nematode L3 (Araujo et al., 2010; Braga et al., 2013a; Braga et al., 2013b; Campos et al., 2009; Gonzales Garduno et al., 2005; Sanyal, 2000). It is known that different isolates of the same species of fungi show various trapping success (Araújo et al., 1993; Den Belder and Jansen, 1994), including $D$. flagrans (Larsen et al., 1991). It is recorded that even equal doses of the same isolates had different efficacy against the same parasite species in separate studies, like Danish isolate $D$. flagrans Troll A versus L3 of Cooperia oncophora, for example (Fernández et al., 1999; Grønvold et al., 2004). Different trapping potency also exists, since some isolates need smaller inoculum size compared to others to obtain good trapping effect (Mendoza de Gives and Vasquez-Prats, 1994). Relative inefficacy of D. flagrans in current trial could be a consequence of poor nematophagous activity of the isolate MUCL 9827.

Predatory activity also depends on ability of the isolate for trap production and on the number of developed traps on surface area unit. Most of authors claim that $D$. flagrans produces traps only following stimulation with nematodes (Rosenzweig, 1984; Den Belder and Jansen, 1994; Boguś et al., 2005; Anan'ko and Teplyakova, 2011). On the contrary, Arias et al. (2013) observed spontaneous trap development of Mexican isolate FTHO-8 after 5 days of growth on corn meal agar. According to Wang et al. (2015), D. flagrans can develop traps spontaneously in case of frequent passage and larval stimulation of an isolate, which was not performed in case of $D$. flagrans MUCL 9827. Direct contact with live and active L3 is a very important stimulus for trap development of $D$. flagrans (Grønvold et al., 1996; Morgan et al., 1997). However, a recent study showed that dead helminths (trematodes and nematodes), as well as their secretory products, also stimulate the production of traps (Arias et al., 2013). Except living nematodes, other soil organisms like earthworms and insect larvae as well as addition of some peptides can also stimulate transformation from saprophytic to predatory phase in closely related species A. oligospora (Nordbring-Hertz, 1977).

According to Anan'ko and Teplyakova (2011), there are two important preconditions for development of traps by D. flagrans. Firstly, the concentration of carbon and nitrogen in growing medium has to be below the threshold required to trigger nutrition stress, and secondly, mycelium has to be stimulated with nematode excretory products or 
by addition of known concentrations of amino acids. When grown on nutrient rich media where nutritious stress is lacking, the fungus develops fewer traps (Morgan et al., 1997; Gonzales Garduno et al., 2005). Rosenzweig (1984) recorded that despite good growth $D$. flagrans failed to produce traps on both nutrient rich and poor media, even after addition of different amino acids and peptides. Traps developed within 24-48 hours only after addition of live nematodes Panagrellus silusiae. Similarly, the presence of L3 of horse cyathostomins was of vital importance for production of traps on 2\% WA for two Brazilian isolates of D. flagrans (AC001 and CG722) (Braga et al., 2011). Substrates poor in nutrients (like 2\% WA) are convenient for trap development since nematophagous fungi use the ability to feed animal organisms only when exposed to nutritious stress (Nordbring-Hertz, 1968). However, it seems that the presence of nematodes is not the sole factor for the development of nematophagous structures, and that this phenomenon is strongly dependent on other factors like nutrient level, temperature, moisture, $\mathrm{pH}$, light, $\mathrm{O}_{2} / \mathrm{CO}_{2}$ level (Nordbring-Hertz, 1968).

Taking into account all previous facts, it was real to expect the occurrence of nematophagous activity of $D$. flagrans MUCL 9827 on 2\% CHF-WA after addition of 1000 active L3 of sheep GIN. All series were cultured under the same conditions (medium, $\mathrm{pH}$, temperature, light, moisture, $\mathrm{O}_{2} / \mathrm{CO}_{2}$ level) and stimulated with the same number and species of L3. Despite this, it seems that only in one plate with fungal material the complex factors were optimal for trap development. Nematophagous activity was recorded in a plate seeded with 1000 chlamydospores, which suggests that critical stress level required for transformation to predatory phase was achieved only in that plate, while it appears that in others there was were still enough nutrients. Boguś et al. (2005) also recorded lack of trap production for five isolates of $D$. flagrans (including MUCL 9827) since, as they concluded, there was sufficient concentration of available carbon and nitrogen which prevented transformation from saprophytic to predatory phase of the fungus on poor nutrient media.

Sufficient level of nutrients could be one of the reasons for absence of nematophagous activity in the current trial. Apart from 2\% WA in series 1, discs of PDA could be the food source for the mycelium. In series 2 seeded with 500 chlamydospores there was, probably, not enough time for the culture to spend all nutrients below stress level, considering the speed of growth of the isolate. In series 3 seeded with 1000 chlamydospores, critical stress level is achieved only in one plate, but lacked in other two.

In vitro trials with nematophagous fungi are commonly performed on agarized media, so the composition of nutrients and biologically active compounds differs in various parts of the substrate (Anan'ko and Teplyakova, 2011). Despite this, the age and physiological maturity of the mycelium is significantly heterogeneous. Therefore, the results of quantitative investigation on the physiology of predatory fungi are often imprecise and variable between studies of different authors (Anan'ko and Teplyakova, 2011). In the current trial, there is a possibility that the traps of $D$. flagrans MUCL 9827 developed on places where the highest number of chlamydospores germinated (the oldest culture), or at places with the lowest concentration of nutrients within $2 \% \mathrm{WA}$, which resulted in their clustered appearance.

It is known that in vitro activity of some isolates of nematophagous fungi does not provide strong indications of their predatory capacity in natural environment, as illustrated by Galper et al. (1995). In their trial, Dactyella candida 023 and Arthrobotrys dactyloides A4 showed very poor activity on corn meal agar compared to soil, opposite to nematophagous effect of $A$. oligospora M2. Further experiments using $D$. flagrans MUCL 9827 are needed to more closely evaluate its predatory ability, especially regarding in vivo studies.

\section{CONCLUSION}

Our previous (Simin et al., 2012) and current results showed nematophagous activity of $D$. flagrans MUCL 9827. Although the effect of fungus was poorer in this compared to other studies, certain success was achieved, since this is the first time after more than 65 years following results of Duddington (1949) that D. flagrans MUCL 9827 demonstrated trapping ability.

The isolate was inconsistent in L3 trapping at in vitro conditions of this trial, as shown by the appearance of its activity only in one out of nine plates with fungal material which could be the consequence of absence of nutritional stress. Further investigations are required in order to examine and to understand complex factors that trigger transition of $D$. flagrans MUCL 9827 from saprophytic to predatory phase. Due to potential difference in predatory performance compared to in vitro results, the isolate should be tested in vivo especially since it is not known whether it can survive the passage through gastro-intestinal system of sheep, which is a prerequisite for its use as a successful biocontrol agent in control of GIN infections. 


\section{REFERENCES}

ANAN'KO, G. G., TEPLYAKOVA, T. V.: Factors responsible for transition of the Duddingtonia flagrans carnivorous fungus from the saprotrophic to the zootrophic nutrition type. Microbiology, 80(2): 188-193, 2011.

ARAÚJO, J. V., SANTOS, M. A., FERRAZ, S., MAIA, A. S.: Antagonistic effect of predacious Arthrobotrys fungi on infective Haemonchus placei larvae. Journal of Helminthology, 67(2): 136-138, 1993.

ARAUJO, J. M., ARAÚJO, J. V., BRAGA, F. R., CARVALHO, R. O.: In vitro predatory activity of nematophagous fungi and after passing through gastrointestinal tract of equine on infective larvae of Strongyloides westeri. Parasitology Research, 107(1): 103-108, 2010.

ARIAS, M. S., SUÁREZ, J., CAZAPAL-MONTEIRO, C. F., FRANCISCO, I., LÓPEZ-ARELLANO, M. E., PIÑEIRO, P., PAZSILVA, A.: Trematodes enhance the development of the nematode-trapping fungus Arthrobotrys (Duddingtonia) flagrans. Fungal Biology, 117(7): 540-544, 2013.

BOGUŚ, M. I., CZYGIER, M., KE,DRA, E., SAMBORSKI, J.: In vitro assessment of the influence of nutrition and temperature on growing rates of five Duddingtonia flagrans isolates, their insecticidal properties and ability to impair Heligmosomoides polygyrus motility. Experimental Parasitology, 109(2): 115-123, 2005.

BRAGA, F. R., ARAÚJO, J. V., ARAUJO, J. M., DE OliVEIRA TAVELA, A., FERREIRA, S. R., SOARES, F. E. F., BENJAMIN, L. A. D., FRASSY, L. N.: Influence of the preservation period in silica-gel on the predatory activity of the isolates of Duddingtonia flagrans on infective larvae of cyathostomins (Nematoda: Cyathostominae). Experimental Parasitology, 128(4): 460-463, 2011.

BRAGA, F. R., ARAUJO, J. M., ARAÚJO, J. V. D., SOARES, F. E. D. F., TAVELA, A. D. O., FRASSY, L. N., MOZZER, L. R.: In vitro predatory activity of conidia of fungal isolates of the Duddingtonia flagrans on Angiostrongylus vasorum first-stage larvae. Revista da Sociedade Brasileira de Medicina Tropical, 46(1): 108-110, $2013 \mathrm{a}$.

BRAGA, F. R., ARAÚJO, J. V., TAVELA, A. D. O., VILELA, V. L. R., SOARES, F. E. D. F., ARAUJO, J. M., ATAHYDE, A. C. R.: First report of interaction of nematophagous fungi on Libyostrongylus douglassii (Nematoda: Trichostrongylidae). Revista Brasileira de Parasitologia Veterinária, 22(1): 147-151, 2013b.

CAMPOS, A.K., ARAÚJO, J.V., GUIMARÃES, M.P., DIAS, A.S: Resistance of different fungal structures of Duddingtonia flagrans to the digestive process and predatory ability on larvae of Haemonchus contortus and Strongyloides papillosus in goat feces. Parasitology Research, 105:913-919, 2009.

CHANDRAWATHANI, P., JAMNAH, O., WALLER, P. J., HÖGLUND, J., LARSEN, M., ZAHARI, W. M.: Nematophagous fungi as a biological control agent for nematode parasites of small ruminants in Malaysia: a special emphasis on Duddingtonia flagrans. Veterinary Research, 33(6): 685-696, 2002.

COOKE, R. G.: Two nematode-trapping hyphomycetes, Duddingtonia flagrans gen. et comb. nov. and Monagrosporium mutabilis sp. nov. Transactions of the British Mycological Society, 53(2): 315-319, 1969.

CVETKOVIĆ, LJ.: Hemioprofilaksa značajnijih pašnih helmintoza preživara. Praxis Veterinaria 24(1):23-31, 1976. (in Serbian) DEN BELDER, E., JANSEN, E.: Capture of plant-parasitic nematodes by an adhesive hyphae forming isolate of Arthrobotrys oligospora and some other nematode-trapping fungi. Nematologica, 40(1): 423-437, 1994.

DUDDINGTON, C. L.: A new predacious species of Trichothecium. Transactions of the British Mycological Society, 32(3-4): 284-287, 1949.

FERNÁNDEZ, A.S., LARSEN, M., WOLSTRUP, J., GRØNVOLD, J., NANSEN, P., BJØRN, H.: Growth rate and trapping efficacy of nematode-trapping fungi under constant and fluctuating temperatures. Parasitology Research, 85:661-668, 1999.

GALPER, S., EDEN, L. M., STIRLING, G. R., SMITH, L. J.: Simple screening methods for assessing the predacious activity of nematode-trapping fungi. Nematologica, 41(1): 130-140, 1995.

GRØNVOLD, J., NANSEN, P., HENRIKSEN, S. A., LARSEN, M., WOLSTRUP, J., BRESCIANI, J., RAWAT, H., FRIBERT, L.: Induction of traps by Ostertagia ostertagi larvae, chlamydospore production and growth rate in the nematode-trapping fungus Duddingtonia flagrans. Journal of Helminthology, 70(4): 291-297, 1996.

GRØNVOLD, J., WOLSTRUP, J., LARSEN, M., GILLESPIE, A., GIACOMAZZI, F.: Interspecific competition between the nematode-trapping fungus, Duddingtonia flagrans, and selected microorganisms and the effect of spore concentration on the efficacy of nematode trapping. Journal of Helminthology, 78(1): 41-46, 2004.

GONZALES GARDUNO, R., MENDOZA DE GIVES, P., HERNÁNDEZ, G. T., PÉREZ, C. B., JIMÉNEZ, E. O., MENDO, O. H.: Estudio in vitro de la capacidad depredadora de Duddingtonia flagrans contra larvas de nematodos gastrointestinales de ovinos de pelo. Técnica Pecuaria en México, 43(3); 405-414, 2005.

KAPLAN, R. M.: Drug resistance in nematodes of veterinary importance: a status report. Trends in Parasitology, 20(10): 477481, 2004.

LARSEN, M., WOLSTRUP, J., HENRIKSEN, S. A., DACKMAN, C., GRØNVOLD, J., NANSEN, P.: In vitro stress selection of nematophagous fungi for biocontrol of parasitic nematodes in ruminants. Journal of Helminthology, 65(3): 193-200, 1991.

LARSEN, M.: Biological control of helminths. International Journal for Parasitology, 29: 139-146, 1999.

MAFF (Ministry of Agriculture, Fisheries and Food): Manual of Veterinary Parasitological Laboratory Techniques, ADAS, HMSO, UK, 1986.

MENDOZA-DE GIVES, P., VAZQUEZ-PRATS, V. M.: Reduction of Haemonchus contortus infective larvae by three nematophagous fungi in sheep faecal cultures. Veterinary Parasitology, 55(3): 197-203, 1994.

MORGAN, M., BEHNKE, J. M., LUCAS, J. A., PEBERDY, J. F.: In vitro assessment of the influence of nutrition, temperature and larval density on trapping of the infective larvae of Heligmosomoides polygyrus by Arthrobotrys oligospora, Duddingtonia flagrans and Monacrosporium megalosporum. Parasitology, 115:303-310, 1997. 
NORDBRING-HERTZ, B.: The influence of medium composition and additions of animal origin on the formation of capture organs in Arthrobotrys oligospora. Physiologia Plantarum, 21(1): 52-65, 1968.

NORDBRING-HERTZ, B.: Nematode-induced morphogenesis in the predacious fungus Arthrobotrys oligospora. Nematologica, 23(4): 443-451, 1977.

PAPADOPOULOS, E., GALLIDIS, E., PTOCHOS, S.: Anthelmintic resistance in sheep in Europe: a selected review. Veterinary Parasitology, 189(1): 85-88, 2012.

ROBERTS, F. H. S., O'SULLIVAN, P. J.: Methods for egg counts and larval cultures for strongyles infesting the gastro-intestinal tract of cattle. Crop and Pasture Science, 1(1): 99-102, 1950.

ROSE, H., RINALDI, L., BOSCO, A., MAVROT, F., DE WAAL, T., SKUCE, P., CHARLIER, J., TORGERSON, P. R., HERTZBERG, H., HENDRICKX, G., VERCRUYSSE, J., MORGAN, E.R.: Widespread anthelmintic resistance in European farmed ruminants: a systematic review. Veterinary Record, 176(21): 546, 2015.

ROSENZWEIG, W. D.: Role of amino acids, peptides, and medium composition in trap formation by nematode-trapping fungi. Canadian journal of microbiology, 30(2): 265-267, 1984.

SANYAL, P. K.: Screening for Indian isolates of predacious fungi for use in biological control against nematode parasites of ruminants. Veterinary Research Communications, 24(1): 55-62, 2000.

SARGISON, N. D.: Pharmaceutical treatments of gastrointestinal nematode infections of sheep-Future of anthelmintic drugs. Veterinary Parasitology, 189(1): 79-84, 2012.

SCHOLLER, M., HAGEDORN, G., RUBNER, A.: A reevaluation of predatory orbiliaceous fungi. II. A new generic concept. Sydowia, 51(1): 89-113, 1999.

SHAMS GHAHFAROKHI, M., RAZZAGHI ABYANEH, M., RANJBAR BAHADORI, S., ESLAMI, A., ZARE, R., EBRAHIMI, M.: Screening of soil and sheep faecal samples for predacious fungi: isolation and characterization of the nematodetrapping fungus Arthrobotrys oligospora. Iranian Biomedical Journal, 8(3): 135-142, 2004.

SIMIN, S., LALOŠEVIĆ, V., KURUCA, LJ., ĐURIĆ, S., HAJNAL-JAFARI. T.: Coproculture assay for estimation of in vitro larval reduction of sheep gastrointestinal nematodes by nematophagous fungus, Duddingtonia flagrans. Contemporary Agriculture, 61(3-4): 255-264, 2012.

SIMIN, S., SIMIN, V., KURUCA, LJ., SAVOVIĆ, M., BUGARSKI, D., LALOŠEVIĆ, V.: Preliminary evidence of ivermectin resistance in sheep gastrointestinal strongyles in Serbia. In: Book of Abstracts of Symposium XVI Epizootiology days of Serbia (Zrenjanin, Serbia). 126p, 2014.

SKIPP, R. A., YEATES, G. W., CHEN, L. Y., GLARE, T. R.: Occurrence, morphological characteristics and ribotyping of New Zealand isolates of Duddingtonia flagrans, a candidate for biocontrol of animal parasitic nematodes. New Zealand Journal of Agricultural Research, 45(3): 187-196, 2002.

TERRILL, T.H., LARSEN, M., SAMPLES, O., HAUSTED, S., MILLER, J.E., KAPLAN, R.M., GELAYE, S.: Capability of the nematode-trapping fungus Duddingtonia flagrans to reduce infective larvae of gastrointestinal nematodes in goat feces in the southeastern United States: dose titration and dose time interval studies. Veterinary Parasitolology, 120:285-296, 2004.

VUJIĆ, B., ANIĆ, N., BOŠKOVIĆ, V.: O antiparaziticima i značaju njihove upotrebe u ovčarskoj proizvodnji. Veterinarski glasnik, 34(8): 735-743, 1980. (in Serbian)

ZAJAC, A.M., CONBOY, G.A.: Veterinary clinical parasitology. Oxford: Blackwell Publishing, 2006.

WALLER, P. J., FAEDO, M.: The potential of nematophagous fungi to control the free-living stages of nematode parasites of sheep: screening studies. Veterinary Parasitology, 49(2-4): 285-297, 1993.

WALLER, P. J.: International approaches to the concept of integrated control of nematode parasites of livestock. International Journal for Parasitology, 29(1): 155-164, 1999.

WANG, B. B., LIU, W., CHEN, M. Y., LI, X., HAN, Y., XU, Q., LIU, J. L.: Isolation and characterization of China isolates of Duddingtonia flagrans, a candidate of the nematophagous fungi for biocontrol of animal parasitic nematodes. Journal of Parasitology, 101(4): 476-484, 2015.

WEST, D.M., POMROY, W.E., KENYON, P.R., MORRIS, S.T., SMITH, S.L., BURNHAM, D.L.: Estimating the cost of subclinical parasitism in grazing ewes. Small Ruminant Research, 86:84-86, 2009.

\title{
NEMATOFAGNA AKTIVNOST DUDDINGTONIA FLAGRANS MUCL 9827 PROTIV ŽELUDAČNO-CREVNIH STRONGILIDA OVACA
}

\author{
Stanislav SIMIN, Simonida ĐURIĆ, Ljiljana KURUCA, Timea HAJNAL-JAFARI, Dragana STAMENOV, \\ Vesna LALOŠEVIĆ
}

Izvod: Želudačno-crevne strongilide ovaca predstavljaju jedno od najvažnijih ograničenja u pašnom uzgoju ovaca širom sveta. Uobičajeno je da se kontrolišu primenom antihelmintika, ali globalno pojavljivanje rezistencije na različite lekove $i$ širenje multirezistentnih izolata strongilida ozbiljno ograničavaju njihovu efikasnost. Stoga, preporučuje se integrisani pristup kontroli parazita, gde je primena nematofagnih gljiva jedna od metoda. Duddingtonia flagrans je jedna od najviše korišćenih vrsta, uz varijacije u efikasnosti različitih izolata. U prethodno urađenom testu koprokulture, zabeležili smo nisku efikasnost D. flagrans MUCL 9827 protiv infektivnih larvica (L3) strongilida ovaca. Cilj ogleda je da se ponovo proceni nematofagni potencijal izolata na medijumu gde se može direktno posmatrati interakcija gljive i L3. Nematofagna aktivnost je ispitana na $2 \%$ gladnom agaru sa 
dodatkom hloramfenikola u tri serije Petri kutija zasejanih sa 500 i 1000 hlamidospora i komadićima agara sa sedmodnevnom kulturom micelijuma. Radi ispitivanja aktivnosti, u svaku kulturu je dodato po 500 L3 strongilida ovaca na dan 0 i 5 . Kulture, uključujući i kontrolu bez gljive, su inkubirane na $25^{\circ} \mathrm{C}$ tokom 10 dana nakon čega je usledila evaluacija broja i procenta redukcije L3. Nematofagna aktivnost D. flagrans MUCL 9827 protiv L3 strongilida ovaca je jasno dokazana. Međutim, ukupna efikasnost gljive je bila slaba jer je hvatanje zabeleženo samo u jednoj kulturi od devet zasejanih. Mogući razlozi za tako slab efekat ovog izolata vrste koja je inače poznata po uspešnosti u hvatanju parazitskih nematoda životinja su diskutovani.

Ključne reči: Duddingtonia flagrans, MUCL 9827, ovce, želudačno-crevne strongilide, nematofagna aktivnost.

Received / Primljen: 14.10.2016.

Accepted / Prihvaćen: 28.11.2016. 